\title{
What is the Nature of the Signal for Precise Localization of the Glycosylation-Modifying Enzymes in the Golgi Apparatus?
}

\author{
糖鎖修飾酵素がゴルジ体に正確に局在するために必要なシグナルは？
}

Munro, S. (1995) EMBO J. 14, 4695-4704

\begin{abstract}
Key Words:Golgi apparatus, glycosylation-modifying enzyme, kin recognition, retention, transmembrane domain
\end{abstract}
The secretory pathway of eukaryotic cells consists of a series of discrete organelles between which transport occurs by a process of vesicle budding and targeted fusion. Among these organelles, the Golgi apparatus serves a central role in directing incoming soluble and membrane-bound proteins from the endoplasmic reticulum (ER) to different subcellular compartments, cell surface, and to outside of the cell. It is widely believed that secretory proteins or intrinsic membrane proteins expressed at cell surface are transported by default, while the resident proteins of the secretory pathway contain information in, for instance, their primary sequence which determines their precise location. Localization of resident proteins is accomplished by two targeting mechanisms: protein retention and retrieval of proteins from a later compartment. As for Golgi-resident proteins, the former process has so far been reported.

The Golgi membrane proteins are known to be involved in a variety of important post-translational modifications of proteins such as $N$ - and $O$-glycosylation. The glycosylationmodifying enzymes (glycosyltransferases and glycosidases), which are type II membrane proteins, should thus have a targeting mechanisms to organize and complete glycosylation reactions precisely. It has been suggested from previous studies that transmembrane domain (TMD) has a major effect on the retention of the glycosylation-modifying enzymes. Although the mechanism underlying this TMD-mediated retention has not been resolved, there are a few models hypothesized so far, one of which is the 'kin recognition' model have been [Nilsson, T., et al., (1993) FEBS Lett. 330, 1]. According to the model, Golgi enzymes destined to localize at the same subcellular compartment form hetero-oligomers, which are too large to enter into forward-moving transported vesicles, presumably by interaction through their TMDs. This hypothesis is supported by the observation that artificial retention in the ER of the medial-Golgi enzyme GlcNAc-transferase I results in the retention of another enzyme of medial-Golgi, $\alpha$-mannosidase, in the ER [Nilsson, T., et al., (1994) EMBO J. 13, 562]. However, unlike the cases for ER-retrieval signals, attempts to define the critical residues important for the protein retention have been in vain. On the other hand, the author showed previously that $\alpha-2,6$ sialyltransferase (ST), a trans-Golgi enzyme, was still retained
真核細胞における分泌経路は、オルガネラ間を輸送小胞が 出芽し、標的器官の膜と融合するという一連の過程によって構 成されている。そのようなオルガネラの内、ゴルジ体は小胞体 (ER)から輸送されてきたタンパク質を様々な細胞内コンパート メントや細胞表面、あるいは細胞外への分泌へ、と分類して輸 送する重要な役割を担っている。一般的に、細胞内に留まる夕 ンパク質は例えばその一次構造上に正確な局在部位を規定する 情報が組み込まれているのに対し、そういった情報がない夕ン パク質は、膜タンパク質の場合細胞表面に、そして可溶性タン パク質は分泌されると考えられている。ある細胞内コンパート メントへの局在の機構は現在のところ2つが知られている。即ち タンパク質が特定の膜系に停留する(retention)様式と、分泌経路 上の下流のコンパートメントから標的のオルガネラに戻される (retrieval)様式である。そのうち、ゴルジ体に局在する機構につ いては専ら停留によるものが今までに報告されている。

ゴルジ体局在タンパク質は、アスパラギン型糖鎖やセリ ン・スレオニン型糖鎖の付加、修飾を初めとした種々のタンパ ク質翻訳後修飾に関与していることが知られている。それ故、 II型の膜タンパク質である糖鎖の修飾に関与する糖転移酵素やグ リコシダーゼは、糖鎖の修飾反応が正確に完遂されるためにゴ ルジ体内に整然と分布する必要がある。よって厳密にそれらの 分布を規定する機構が存在するはずである。以前の研究から、 糖鎖修飾酵素のゴルジ体への停留にはその膜貫通ドメイン (TMD)が重要な役割を果たすことが知られているが、それがど ういった機構によるものかについては未解決であり、定説がな い。その機構について今までに提唱された仮説の内、有名なも のに“親族認識(kin recognition)”モデルがある[T. Nilssonら (1993) FEBS Lett. 330, 1]。その仮説によると、同じ細胞内コンパート メントに局在する酵素はTMDを介した相互作用によってへテロ オリゴマーを形成し、その複合体が大き過ぎるためにその先に 進む輸送小胞に入ることができずに、標的のオルガネラに留ま る、といった機構が考えられている。事実、メディアルゴルジ の䤉素であるGlcNAc転移酵素 I の局在を人為的にERに変えてや ると、他のメディアルゴルシ酵素である $\alpha$-マンノシダーゼもER に局在するようになり、上述の仮説が支持された[T. Nilssonら (1994) EMBO J. 13, 562]。しかしながら、ERへの差し戻しシグ ナルの場合と異なり、TMD上に停留に重要な一次構造上の情報 は見い出すことができなかった。一方、以前ここに紹介する論 
in the Golgi if the 17 residues of TMD are replaced by 17 leucines but not if they are replaced by 23 [Munro, S. (1991) EMBO J. 11, 3577], which led him to demonstrate another model in which TMD determines the behaviors of proteins in the secretory pathway by virtue of differences in their physical properties, that is, their length [Bretchers, M.S. and Munro, S. (1993) Science 261, 1280]. In this paper, the features of the two models described above, as they pertain to a trans-Golgi enzyme, $\alpha$-2,6-sialyltransferase (ST), are investigated.

First, the author expressed ST with an ER-retention signal, KDEL, attached to its C-terminus in COS cells to evaluate if the 'kin recognition'worked between ST and another transGolgi enzyme, $\beta$-1,4-galactosyltransferase (GT). As expected, the construct was accumulated in the ER, while GT still remained in the Golgi, suggesting that ST does not appear to form specific kin interactions, at least with GT in the ER. Moreover, the critical region for interaction between medial enzymes, GlcNAc-transferase I and $\alpha$-mannosidase, was determined using similar assay for trans-Golgi enzymes. Surprisingly, it was revealed that the medial-Golgi enzymes seemed to be interacted by their lumenal domains rather than by TMDs.

As the next step, to validate the other hypothesis that he proposed, the effects of altering the length of TMD of ST were examined. The result showed that the longer insertion to the TMD was found to have a critical effect for the Golgi retention, demonstrating that the length of TMD does have a significant role for Golgi retention. Conversely, when the length of TMD of a type II plasma membrane protein was shortened to that of ST, alteration of the intracellular localization of the enzyme to the Golgi was observed. Furthermore, the TMD of ST was able to function as a Golgi-retention signal even if it was attached to a type I membrane protein with reverse orientation. Taken together, it was clearly shown that TMD length was a critical feature of the Golgi retention signal of ST.

The results presented here are simple and clear, and we can easily accept the idea that the TMD affects the intracellular distribution of the protein by virtue of its length. As for the mechanism to act as a sorting by length of TMD, the author has proposed that a change in the lipid composition along the secretory pathway might be involved. Actually the the gradient of increasing cholesterol and sphingolipid, which causes the membrane to thicken, from ER to plasma membrane in accordance with the direction of the secretory pathway was observed. A shorter TMD of Golgi-resident proteins will thus make it energetically unfavorable to enter a cholesterol and/or sphingolipid-rich domain where the bilayer is thicker and transport vesicles for plasma membrane would be formed. It seems reasonable considering the requirement of biological function of each membrane (for details, I encourage all readers to refer to his original papers), and the notion that the Golgi can be regarded as the site of a fundamental transition in the internal
文の著者はSTの17残基のTMDをすべてロイシンに变換してもゴ ルジ体に停留するが、23残基のロイシンに变換すると停留でき ないことを明らかにし、[S. Munro (1991) EMBO J. 11，3577]この ことからTMDの物性、即ち長さが分泌過程においてその夕ンパ ク質の局在を規定する、という別のモデルを提唱している[M.S. Bretchers とS. Munro (1993) Science 261, 1280]。本論文では上述 の2つのモデルがトランスゴルジの酵素である $\alpha-2,6$-シアル酸転 移酵素(ST)について当てはまるか否かが検討された。

まずSTと別のトランスゴルジ酵素であるß-1,4-ガラクトー 又転移酵素(GT)の間に所謂kin recognitionが働いているか否か を、STのC末端にER輸送シグナルであるKDELを付加した融合 タンパク質を作ることによって調べられた。期待通りSTの構築 変異タンパク質はERに蓄積されたがGTはゴルジ体に局在したま まで、少なくともこの2つのタンパク質間において特異的なkin recognitionは㗢いていないと考えられた。その上、以前にkin recognitionが認められたメディアルゴルジ酵素であるGlcNAc転 移酵素Iと $\alpha$-マンノシダーゼについて、同様のアッセイ方法で その相互作用に重要な部位を特定したところ、驚いたことに両 者の相互作用は以前言われているようにTMDを介したものでな

く、むしろルーメン側で起こっていることが示された。

次にSTのゴルジ局在化機構のもう一つの仮説を検討するた め、STのTMDの長さの变化がその局在に与える影響が調べられ た。その結果、STのTMDにアミノ酸を挿入することによってゴ ルジ体への停留能が失われることが分かり、やはり TMDの長さ がその局在機構に寄与していることが確かめられた。逆に、II型 の細胞膜上のタンパク質のTMDを短くすることによってゴルジ 体に局在するようになることも分かった。さらにSTのTMDを逆 向きにしてI型の膜タンパク質に導入したところ、やはりゴルジ 体に局在するようになり、STのTMDのゴルジ体への停留能の普 遍性が証明された。これらの結果から、STのTMDの長さがゴル ジ体への停留のシグナルとして機能していることが明確に示さ れた。

本論文の論旨は平易かつ明快で、TMDの長さが細胞内の局 在のシグナルとなっている、というモデルは説得力がある。 TMDの長さが夕ンパク質の局在を規定する機構としては、著者 は分泌経路上の各オルガネラに扔ける脂質の組成の違いが関与 している、と推測している。実際にERから細胞膜にかけて分泌 経路の進行方向に従ってコレステロールやスフィンゴ脂質の含 量が増加することが実験的に知られている。そのような脂質の 増加は膜の肥厚をもたらす。従って、TMDの短いゴルジ体局在 タンパク質がコレステロールやスフィンゴ脂質に富み厚さが増 した膜に入るのはエネルギー的に不安定であり、その結果細胞 膜への輸送小胞に入り込めない、というモデルが考えられる。 異なる膜系において脂質の組成が違うことは、細胞内での各々 の役割を考えるととても合理的でありにの辺の内容の詳細につ いては、是非本著者の原著論文を参照することをお勧めした い、ゴルジ体が各コンパートメント膜の異なる脂質組成を保つ ために非常に重要な役割を果たしている、という概念はとても 興味深い。とにかくここで指摘し得ることは、ゴルジ体への停 
membranes of the cell to maintain different types of bilayer is intriguing. In any case, the important point that should be noted here is that the Golgi retention did not appear to be determined by a single mechanism. I suppose that the length of the TMD does provide the localization of membrane-bound proteins in the Golgi at rather fundamental level, that is, whether or not they should be sorted to the plasma membrane. It will thus be crucial for trans-Golgi proteins in particular. There should also be, however, the mechanism that defines more precisely localization of the resident proteins, since the Golgi resident proteins should discern precisely the targeted subdomains in the Golgi, which go from cis- to trans. Kin recognition may be one such mechanism, although how the TMD contributed to the retention mechanism remains to be determined. Similar studies for several Golgi-resident proteins would seem necessary in order to generalize and understand the overall retention mechanism. But at least for those who have held the blind belief that the primary structure is of "primary" importance for the sorting signals, this paper shows another reliable concept for the retention mechanisms, and is very promising in this sense.

What is the nature of the signal for precise localization of the glycosylation-modifying enzymes in the Golgi apparatus ? The sole answer we can give to that question at present seems to be, "It is not simple mechanism."

\section{Reported by Suzuki, Tadashi}

Department of Biophysics and Biochemistry, Graduate School of Science, University of Tokyo, Hongo-7, Tokyo 113, Japan
留の機構は一つのモデルだけでは説明できないだろう、という ことである。私が受ける感触としては、恐らくTMDの長さによ る局在機構はどちらかというとタンパク質が細胞膜に行くべき か否か、といった根本的な分類に関与していて、特にゴルジ体 の出口にあたるトランスゴルジ局在タンパク質にとっては重要 な機構であるのだろう。しかしながらゴルジ体はシスからトラ ンスまで幾つかの部位に分かれているので、それを正確に区別 する機構が別に存在しなくてはならないのもまた事実であろ う。 kin recognitionはそういった細かい分別の機構の一つとして 存在すると思われる(もっともその認識にかかわる部位について は本論文と以前の報告に矛盾があり、特にTMDがその認識にど のように関与するかは、解決されるべき課題である)。結局ゴル ジ体へのタンパク質停留機構の全容解明には、さらに本論文と 同様の検討が様々なタンパク質においてなされ、データが蓄積 される必要があると思われる。しかしながらタンパク質の選別 (sorting)はその一次構造に依拠するだろう、と勝手に思い込んで いる人達も少なからずいる中(恥ずかしながら私もそうだった)、 本論文は少なくともそういった人に別の信憑性の高い可能性を 指摘したことになり、その意味で非常に示唆に富んでいるとい えよう。

一体、糖鎖修飾酵素がゴルジ体に正確に局在するために必 要なシグナルは何なのであろうか? 今のところ、そのような問 いかけに私達が用意出来る唯一の答えは、“単純ではないよ”と いった感じであろうか。

東京大学大学院 ·理学系研究科. 生物化学専攻 鈴木 匡 